\title{
MECHANISMS OF FORMATION OF WELDING AEROSOL SOLID COMPONENT AND PATHS OF ITS PENETRATION INTO THE LIVING ORGANISM (Review)
}

\author{
I.P. GUBENYA and I.R. YAVDOSHCHIN \\ E.O. Paton Electric Welding Institute, NASU \\ 11 Kazimir Malevich Str., 03680, Kiev, Ukraine. E-mail: office@paton.kiev.ua
}

\begin{abstract}
The paper presents a review of current state of the issue of studying the mechanism of welding aerosol (WA) formation, dispersity of welding aerosol solid component and its ability to penetrate into the human body, as an important toxicological factor. It is established that there exist two main mechanisms of WA formation - due to condensation of high-temperature evaporation products and due to formation of volatile oxides on molten metal surface. Here, the molten metal drop is the main evaporation source, but weld pool and metal spatter also participate in the evaporation process. It is known that penetrability depends, chiefly, on dimensions of particles and their agglomerates: the smaller their size, the higher the penetrability. In addition to the already known paths of WA particle penetration into the body through the respiratory tract and digestive organs, nanosized particles can penetrate directly into the brain through nerve endings in the sinuses, as well as penetrate into the blood-vascular and lymphatic systems. This results in their accumulation in the bone marrow, lymph nodes, spleen and heart. Issue of searching for the methods to lower the emissions in coated-electrode welding is still urgent, chiefly due to improvement of their coating composition, as well as the ability to control particle dispersity in WA. 25 Ref., 1 Figure.
\end{abstract}

Ke yw or d s : particle, welding aerosol, solid component, toxicity, penetrability, sanitary-hygienic characteristics

Coated electrodes for manual arc welding (MAW) have for a long time been the object of investigations, which were initially aimed at improvement of weldingtechnological characteristics, while the next stage was lowering their production cost. At present, electrode sanitary-hygienic characteristics and searching for ways of reducing the negative influence of welding process on workers in this sector, are one of priority directions of electrode research.

As manganese is the main toxic component of welding aerosol (WA) in welding low-alloyed lowcarbon steels, it was and still is one of the main objects of research [1]. This is confirmed by the Bulletin published by IIW, which actualizes the issue of WA investigation and gives several recommendations [2]:

- influence of WA and dust magnesium-containing compounds in welding and related technologies should be minimized, at least, within the respective national norms;

- it is worthwhile to perform further investigations to improve the understanding of absorption of these compounds (welding products); their behaviour in the human body; dose-effect interaction and any possible neurological and neurobehavioural manifestations.

On the other hand, American Conference of Governmental Industrial Hygienists (ACGIH) in 2013 revised their recommendations on manganese and proposed lowering the maximum allowable concentrations (MAC) of manganese: for WA solid component (WASC) with particle size below $2.5 \mu \mathrm{m}$ - to $0.02 \mathrm{mg} / \mathrm{m}^{3}$, and for WASC with more than $2.5 \mu \mathrm{m}$ particle size - to $0.1 \mathrm{mg} / \mathrm{m}^{3}$ [3]. Over the next several years, the above innovations can acquire the normative status that makes welding consumable manufacturers look for ways for adaptation to the new conditions. Such interest is due to the need to solve the questions concerning WASC adverse influence and consequences for the human body, as legal proceedings between welders, who acquired occupational diseases and welding consumable manufacturers are in progress in many countries, particularly, in the USA. The above data indicate that work aimed at improvement of sanitary-hygienic characteristics is carried on interstate level.

This paper analyzes published sources, concerning modern concepts of the mechanisms of WA formation and paths of their penetration into the human body.

MAW involves heating and melting of the electrode and base metal, and as metallic materials are a potential vapour source at heating, these processes of high-temperature heating are accompanied by evaporation of part of base metal and electrode material (1-3\% in coated-electrode welding) [4].

After melting, the molten metal passes the stages of drop and pool. It is believed that there exist three sources of WA formation [5]: molten drops, both present at the electrode tip and at the moment of their 
transition through the arc into the weld pool; weld pool; and spatter.

The drop is the main source of high-temperature vapour, as it is characterized by high specific surface (by an order of magnitude larger that that of the weld pool) and higher overheating level $[6,7]$. Value of drop temperature at the moment of their detachment from electrode tip reaches $2500 \mathrm{~K}$. Moreover, melt temperature in active spot zones is sometimes higher than boiling temperature. After the drop detachment from the electrode tip, its contribution into WA formation decreases [8]. At penetration of the formed vapour-gas mixture (the Figure) beyond the boundaries of the arc shielding atmosphere, intensive oxidation of some condensation products takes place under the influence of ambient oxygen. At cooling of the formed vapours, the condensation centers can be both the atoms of elements proper, and the finest metal drops, which are removed from the arc zone [1].

Work by Heile and Hill [9] gives two mechanisms of aerosol formation. The first consists in evaporation of electrode and base metal components, their subsequent condensation and oxidation. The second mechanism is formation of volatile oxides on molten metal surface in the case of oxygen penetration into the arc atmosphere. The contribution of each of these mechanisms depends on the welding process, composition and oxidizing potential of the arc atmosphere, at lowering of which the role of the second mechanism becomes smaller.

In the case of short-circuiting metal transfer and globular metal transfer, at the end of short-circuiting period, as well as at the moment of drop detachment from the electrode tip, breaking up and explosive evaporation of the formed bridge (neck) of metal between the electrode and base metal takes place, resulting in molten metal spatter. Rather fine spatter, which can remain suspended in the air flow, is called «microdrops». Technically, these microdrops are not

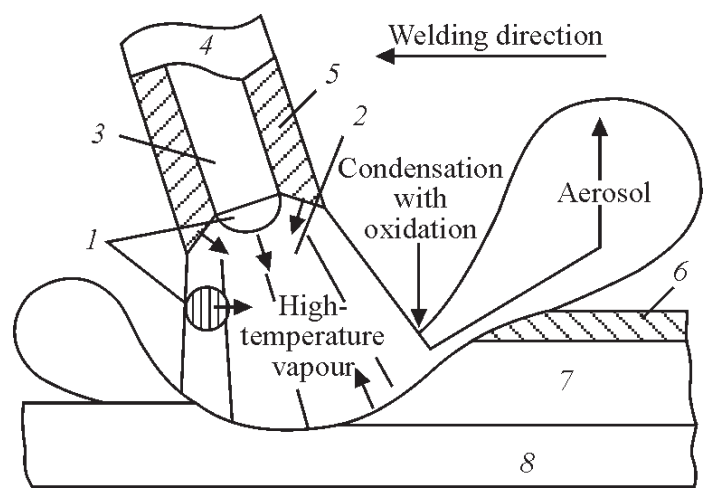

Mechanism of welding aerosol formation [1]: 1 - drop; 2 - arc; 3 - electrode rod; 4 - electrode; 5 - coating; 6 - slag; 7 weld metal; 8 - base metal aerosol, but all the WASC suspended in the air flow are assumed to be WA.

Microdrops can also be an aerosol source, as penetrating into the ambient atmosphere, they intensively evaporate and oxidize that is accompanied by active evolution of aerosol $[10,11]$. Contribution of the above mechanism decreases with reduction of the number of short-circuits, and change of the mode of molten metal transition through the arc.

By the nature of formation, WA belong to condensation aerosols, which are a dispersed system, where nanosized or micron $(0.001-10 \mu \mathrm{m})$ solid particles - WASC, are the dispersed phase, and gas or a mixture of gases (WA gaseous component (WAGC) are the dispersion medium. One of the important factors, determining WASC toxicity, is its dispersity. All the WA formed at any arc welding processes, without exception, are harmful to health. The difference is only in the degree of harmfulness and hazard for the welder that, in its turn, depends on WASC and WAGC composition, as well as on the level of effective concentrations and time of such influence [12].

WASC consists of particles of spherical and nonspherical form and their agglomerates. Most of the particles are of heterogeneous structure, consisting of the core and shell $[10,13]$. The core consists mainly of iron and manganese compounds, and the shell contains silicon, potassium and sodium compounds. Coalescence of WASC particles (agglomeration and aggregation) results from the impact of electrostatic and adsorption forces. Considering the formation mechanism and size of particles, we can assume that electrostatic forces of interaction of WA particles are approximately the same in different materials. The force of adsorption interaction depends on the quantity of alkali elements (potassium, sodium and lithium) in WA. With increase of these elements content, the quantity of particles in agglomerates rises, and the size of agglomerate proper increases, accordingly. Partially sintered agglomerates, agglomerates with «open» structure, forming as a result of action of Van der Waals forces, adsorption forces of atmospheric moisture and electromagnetic forces, are observed, as well as agglomerates of nanosized particles in the form of chains [14-16].

Dimensions of individual particles and agglomerates vary from several nanometers to tens of micrometers [17-19]. About 70-80\% of particles of up to $0.1-2.0 \mu \mathrm{m}$ diameter, penetrating into the body through respiratory organs, are removed when exhaling. Larger diameter particles are removed through expectoration [20].

WASC particles of 2.5-10 $\mu \mathrm{m}$ diameter are defined as those, which can penetrate inside the body with the 
flow of inhaled air - they usually penetrate into the bronchi. Particles of less than $2.5 \mu \mathrm{m}$ diameter can not only penetrate inside the body, but also reach the finest recesses of the lungs - alveole, where the process of gas exchange with the nearest blood vessels proceeds. Penetrating into the alveole, the particles may dissolve and penetrate into the blood flow, as well as physically penetrate through vessel walls and be transported in the solid state by the blood. More over, they can diffuse into different parts of the respiratory tract, can be transported through epithelial and endothelial cells into the blood vascular and lymphatic systems, resulting in their accumulation in the bone marrow, lymph nodes, spleen and heart $[21,22]$. Nanosized WASC can penetrate through the skin [22]. Particularly hazardous is the ability of nanosized particles to penetrate into the brain through nervous endings in the sinuses, overcoming the protective functions of the living organism [23-25]. For comparison: cell size is equal to $1-10 \mu \mathrm{m}$, that of viruses - 20-450 $\mathrm{nm}$, and protein molecules 5-50 nm [22].

Presented data from published sources demonstrate the mechanisms and sources of WA formation, main characteristics of WA particles and its hazard for human health. It is found that penetrability of WASC particles and agglomerates depends on their size: with decrease of the latter their penetrability into the body, either through the respiratory organs, or through the skin, increases. Particles in the nanorange are the most hazardous.

Proceeding from the above data, it is urgent to continue investigation of WASC properties, searching for ways to influence particle dispersity to increase their dimensions, and to lower their penetrability, accordingly, and at the same time, lower their toxic effect on the living organism, and improvement of electrode coating composition to reduce WA emissions.

1. Pokhodnya, I.K., Gorpenyuk, V.N., Milichenko, S.S. et al. (1990) Metallurgy of arc welding: Processes in arc and melting of electrodes. Ed. by I.K. Pokhodnya. Kiev: Naukova Dumka.

2. IIW statement on manganese. https://app.aws.org/technical/ iiw-manganese.pdf

3. Clark, D. (2014) What the recent recommendation on manganese exposure means to you. Welding J., 93(8), 36-40.

4. Jenkins, N., Moreton, J., Oakley, P. et al. (1981) Welding fume. Sources, characteristics, control, Vol. 1-2, 269-329. Cambridge: Abington Hall.
5. Dennis, J.H., Hewitt, P.J., Redding, C.A.J. et al. (2001) A model for prediction of fume formation rate in gas metal arc welding (GMAW), globular and spray modes, DC electrode positive. Ann. Occup. Hyg., 45, 105-113.

6. Erokhin, A.A. (1964) Kinetics of metallurgical processes of arc welding. Moscow: Mashinostroenie.

7. Kobayashi, M., Maki, S., Hashimoto, Y. et al. (1978) Some consideration about the formation mechanisms of welding fume. Welding in the World, 16(11/12), 238-245.

8. Leskov, G.I. (1970) Electric welding arc. Moscow: Mashinostroenie.

9. Heile, R., Hill, D. (1975) Particulate fume generation in arc welding processes. Welding J., 7, 201-210.

10. Voitkevich, V. (1995) Welding fumes: Formation properties and biological effects. Cambridge: Abington Publ.

11. Jenkins, N.T., Pierce, W.M.G., Eagar, T.W. (2005) Particle size distribution of gas metal and flux cored arc welding fumes. Welding J., 84, 156-163.

12. Sterjovski, Z., Drossier, J., de Thoisy, E. et al. (2006) An investigation of particulate weld fume generated from GMAW of plain carbon steel. Austral. Welding J., 51(1 $1^{\text {st }}$ quart.), 21-40.

13. Berlinger, B., Benker, N., Weinbruch, S. et al. (2010) Physicochemical characterization of different welding aerosols Anal. Bioanal. Chemistry, 10, 1773-1780.

14. Zimmer, A.E., Biswas, P. (2001) Characterization of the aerosols resulting from arc welding processes. Aerosol Sci., 32, 993-1008.

15. Zimmer, A.E. (2002) The influence of metallurgy on the formation of welding aerosols. J. Envir. Monitoring, 4, 628632.

16. Sterjovski, Z., Norrish, J., Monaghan, B.J. (2008) The effect of voltage and metal-transfer mode on particulate-fume size during the GMAW of plain-carbon steel: IIW Doc. VIII-209208.

17. Sowards, J.W., Lippold, J.C., Dickinson, D.W. et al. (2008) Characterization procedure for the analysis of arc welding fume. Pt 1. Welding J., 87(4), 76-83.

18. Sowards, J.W., Lippold, J.C., Dickinson, D.W. et al. (2008) Characterization of welding fume from SMAW electrodes. Ibid., 4, 106-112.

19. Sowards, J.W., Lippold, J.C., Dickinson, D.W. et al. (2010) Characterization of welding fume from SMAW electrodes. Pt 2. Ibid., 89(4), 82-89.

20. Jankovic, J. (2005) Searching for a relationship between manganese and welding and Parkinson's disease. Neurology, 64, 2021-2028.

21. Demetskaya, A.V., Kucheruk, T.K., Movchan, V.A. (2006) Particles of nanorange: Possible contribution to development of occupationally conditioned pathology. Ukr. Zhurnal Probl. Med. Truda, 1, 62-67.

22. Hoet, P.H.M., Brueske-Hohlfeld, I., Salata, O.V. (2004) Nanoparticles - known and unknown health risks. J. Nanobiotechnology, 12 (2), 15.

23. Glushkova, A.V., Radilov, A.S., Rembovsky, V.R. (2007) Nanotechnologies and nanotoxicology: View of the problem. Toksikolog. Vestnik, 6, 4-8.

24. Raloff, J. (2010) Destination brain. Sci. News, 177(11), 16-20.

25. Oberdoster, G., Zharp, Z., Atudorei, V. et al. (2004) Translocation of inhaled ultrafine particles to the brain. Inhal. Toxicology, 16, 437-445. 